\title{
Smoking Behavior and Human Capital Investment: Evidence from Indonesian Household
}

\author{
Albertus Girik Allo ${ }^{1}$, Ni Made Sukartini ${ }^{2}$, Endah Saptutyningsih ${ }^{3}$
}

\begin{abstract}
This study aims at estimating the difference health and education performance between children with exposure to smoke and those who are not at home. An environment with the extreme smoke condition has adverse health effects. This study utilizes longitudinal data namely Indonesia Family Life Survey period 2007 and 2014 (IFLS4 and IFLS5). We use the Propensity Score Matching (PSM) method and the Average Treatment Effect on Treated (ATT). The health indicator is proxied by body mass index (BMI) and educational achievement proxied with children cognitive ability. The results show that children who grow in a household with active smoker tend to have lower health status and educational attainment compare to children who are not. This study recommends public policy for banning smoking in public areas as well as inside building such as house and office in Indonesia.
\end{abstract}

Keywords: smoking behavior, human capital investment, household, longitudinal data

\begin{abstract}
Abstrak
Studi ini bertujuan untuk mengestimasi perbedaan aspek kesehatan dan prestasi akademik dari anakanak yang terpapar asap rokok dengan yang tidak terpapar asap rokok di rumahLingkungan dengan kondisi asap rokok yang berlebihan akan berdampak negatif bagi kesehatan. Studi ini menggunakan data longitudinal yaitu Indonesia Family Life Survey periode 2007 dan 2014 (IFLS4 and IFLS5). Studi ini menggunakan metode Propensity Score Matching (PSM) dan the Average Treatment Effect on Treated (ATT). Indikator kesehatan diproksi dengan body mass index (BMI) dan capaian pendidikan diproksi dengan kemampuan kognitif anak. Studi ini menemukan bahwa indikator kesehatan dan pendidikan anak-anak yang terpapar asap rokok lebih rendah dibanding anak-anak yang tidak terpapar asap rokok. Studi ini merekomendasikan ada upaya untuk melarang perokok ditempat-tempat umum dan gedunggedung seperti rumah dan perkantoran di Indonesia.
\end{abstract}

Kata Kunci: perilaku merokok, investasi modal manusia, rumah tangga, data longitudinal

\section{How to Cite:}

Allo, A. G., Sukartini, N. M., \& Saptutyningsih, E. (2018). Smoking Behavior and Human Capital Investment: Evidence from Indonesian Household. Signifikan: Jurnal Ilmu Ekonomi. Vol. 7 (2): 233 - 246. doi: http//dx.doi. org/10.15408/sjie.v7i2.5793. 


\section{Introduction}

Smoking habit among adult population has increased steadily. Smoking has become a lifestyle for the majority of an adult not only in developing countries but also developed ones. The number of smokers around the world has reached 5.8 billion in 2014 (Eriksen et al., 2015). Indonesia is one of the fourth countries regarding some active smokers. Approximately 50.6 million of Indonesian's adults (15 years old or above) has become active smokers (Eriksen et al., 2015). Among ASEAN countries, the number and the percentage of adult's smoker in Indonesia are the largest one. Percentage of active adult's smokers by countries (Eriksen, et al, 2015) are: Indonesia 46.16\%, Philippines (16.62\%), Vietnam (14.11\%), Myanmar (8.73\%), Thailand (7.74\%), Malaysia (2.90\%), Cambodia (2.07\%), Laos (1.23\%), Singapore (0.39\%), and Brunei Darussalam (0.04\%). Considering the cumulative percentage of smokers as older age group in Indonesia has reached $89.3 \%$.

The data of smoking regarding economic sense bring alarming information. Population with lowest income group, such as quantile income 4 and 5 are the most active smokers in Indonesia. It was recorded that the number of active smokers in low-income population about $24.3 \%$ in 2007; but the number increased to $24.3 \%$ in 2014 . Active and excessive smoking cigarette can lead to addictive behavior (Leonardi-Bee et al., 2011). In the case of developing countries, particularly Indonesia; addictive on a smoking cigarette is not only negatively related to income level but also on educational achievement. On average low-income families at least have two adults actively smoking. An adult who work in menial categories such as truck and bus drivers; building construction; farmers and other menial categories tend to smoke more intense compare to skilled labor (The Ministry of Health of Indonesia, 2015).

Adverse effects of cigarettes consumption can be classified as monetary cost and health's side effect (Efroymson et al., 2001). According to the data of Ministry of Health of Indonesia (2015), Indonesia suffers economic losses due to cigarettes consumption has reached USD $\$ 18.5$ billion. The consumption cost covers two costs, namely: the direct costs and indirect costs. The direct cost consists of loss of productivity due to early death, sick and accident. The productivity loss can be caused by decreased lung capacity due to smoking. On the other side is an indirect cost for health aspects. This cost is much higher. Research on health indicates that smokers suffer a higher risk of lung cancer; it is estimated about 7.8 times higher compared with those who are not smokers. Male smokers have a risk of experiencing impotence, and this risky is almost 50 percent higher compare to non-smokers. Basic Health Research or Riset Kesehatan Dasar (Riskesdas) 2013, it presents data that indicating about 85 percent of households in Indonesia is exposed to cigarette smoke. The Ministry of Health of Indonesia (2015) estimates that approximately 25,000 of deaths in Indonesia are among passive smokers. Passive smokers are those who are not actively smoke but highly on exposed by smoke; therefore are at risk on the health side.

Children who live in families where their parents or other people are actively smoking will cause a reduction in the health of children in the future. The children become a secondhand smoker or passive smokers and active smokers (Hill et al., 2005; Pust et al., 2008). Empirical study reports there are various potential health problems related to cigarette smoke 
such as lung capacity reduction (Cook et al., 1998; Moshammer et al., 2006); potential affected by asthma symptoms (Cook and Strachan, 1997; Duelien et al., 2005; Strachan and Cook, 1997); easily influenced by the diseases (Nageris, et al, 2001) and increase the risk of child malnutrition (Best, et al, 2007; Semba, et al, 2007). Lower levels of the health on children will cause lower levels of productivity and lower the education processes. Priest et al. (2008) find that children who are secondhand smokers tend to have lower levels of education compared with children who are not in the family without smokers. Heckman and Masterov (2007) find that children who live in an environment of less fortunate (disadvantaged environmental) will tend to have a lower level of productivity in their productive age. The case of poor families in Indonesia, paternal smoking has been shown to shift spending from fruit and vegetables to consume cigarette and sharpen child malnutrition (Semba et al., 2007) and increase under-five mortality (Semba et al., 2008).

Transmission between health status in the younger lifetime and the consequent on the quality of life in the future is explained by two-period overlapping generation model (Becker and Tomes, 1986). Some children are lucky enough for being born in families with a good quality genetic attribute, which is innate to the children. Genetic factors are exogenously affected by the quality of individual's health in the future. If this variable is assumed to be a given or exogenously determined, then the parent cannot control it. However, human resource investment is not only affected by genetic quality but by various factors. Factors are among of these: the level of health at birth, living conditions, learning and motivation of the parents. For example, as long as the child is in the womb, the mother can invest in nutritious food and avoid the smoking behavior. Economic and health model proposed by Becker and Tomes (1986) indicated that parents through their genes are assumed having an essential role in determining the welfare including health status of their child in the future. This model is built based on altruistic assumption. Altruistic assumes that parents care a lot for their child, and the utility function of their child is part of the utility function of the parents.

The level of individual health is not only influenced by biological processes but is related to the environmental conditions. Case and Deaton (2005) revealed that the health of children in the future also determined by the quality of foods consumed by the children in their early age. Refer to this assumption this means that a child born to the poor family might have potential lower human resources in the future.

This study investigates the contagious effects of continuous smoke from smokers on the socioeconomic status of children. We focus these effects on health and education attainment. In other words, do children grow up with active smokers tend to have lower performance in health and education? There are various health status indicators on an adult. We consider health performance as Body Mass Index (BMI) measured by the comparison of the individual body weight $(\mathrm{kg})$ with body high $(\mathrm{cm})$. Regarding educational indicator, we consider the function of the logic of the children; this is known as child cognitively intact function. The results of this study are expected to be a reference to reduce the risk caused by exposure to cigarette smoke, especially for children. 


\section{Method}

This research utilizes data from Indonesia Family Life Survey (IFLS) or previously known as a survey of aspects of Household Life Indonesia (Sakerti). IFLS is a longitudinal and national broad survey on a household level in Indonesia. This research utilizes the IFLS4 and IFLS5 data. The reason is only the last two waves of IFLS contains information about smoking habit. The IFLS4 is determined as baseline data, and IFLS5 used to view the outcome. Children surveyed in IFLS4 were in 1-14 years old, by the time of the survey in the IFLS5 is conducted, these children have reached age of 8-21 years old. The definition of children based on Act No. 23 the year 2002 about child protection is a person who has not yet aged 18 (eighteen years, including children who are still in the womb). Children are considered able to make their own decisions by the age of 14 years old or above. In many developed countries, children under age 14 are eligible to reside separately from their parent house. In Indonesia, this trend is practically adopted recently. Children can reside in their place for the reason of schooling. At the same time, the number of the children who are actively smoking for the aged more than 14 years getting higher (The Ministry of Health of Indonesia, 2015).

This study follows Johnson and Schoeni (2011) for estimation strategy. To investigate the relationship between health and economic status, this study analyzes the health conditions at the initial period of the life of the son. In this case, we investigated children age below 18 years old in 2007. We set this data as IFLS4 and called it as the baseline year. This research tries to proxy conditions at the beginning of the life of children who are experienced high exposure to cigarette smoke from their parents or adult in the household. These children belong to the category of passive smokers or secondhand smokers. The results of research carried out in several countries shows that secondhand smoker can affect the health and productivity of children in their productive ages. Impact of smoke exposure on children is investigated through a sample of children in their later life, i.e. data of IFLS5. We focus the investigation on the effect on education and health indicator. Education indicator is proxied by cognitive ability, and health indicator is proxied by children's BMI. Put it diagrammatically, as shown in Figure 1.

Figure 1. Estimation Strategy

Children life with adult who are actively smoking in 2007 (IFLS4)

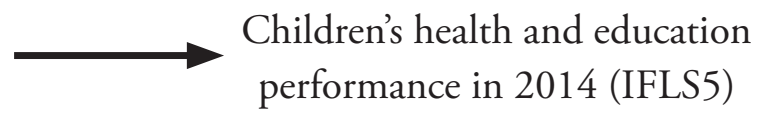

This study, the main source of potential bias is the design of smokers in the family of non-random selection. This problem will cause bias the estimation if we compare directly the outcome of children living in the family of smokers with non-smokers (compare control and treatment without PSM in figure 2). To overcome the potential bias from sample selection, this study utilizes Propensity Score Matching (PSM) and community participation (CP) to compare the outcome between treatment groups and control group (compare control and treatment with PSM in Figure 2). To compare the outcome, the PSM technique comparing individual characteristics from the two groups. The important things that need attention in 
this model are common support, where more characteristic of individual or households who used the more small differences between treatment groups and control (Heckman and Robb, 1985). The assumption that must be met in the estimation bias is viewing the impact from the presence of smokers in the family against the outcome, is:

$$
\left[E\left(Y_{i, t+p}^{0} \mid M_{i}^{*}, m_{i}=1\right)-E\left(Y_{i, t+p}^{0} \mid M^{*}{ }_{i}, m_{i}=0\right)\right]=0
$$

Where,

$Y^{0} \quad$ outcome of children

$M^{*}{ }_{i}=\Phi\left(X \gamma^{*}\right)$ propensity score.

$m_{i}=1$ If the children are in a family of smokers, $0=$ other.

$t \quad=$ baseline year (IFLS4)

$\rho \quad=$ The number of years when the outcome is measured

Figure 2. Evaluation Using a With-and Without Comparison

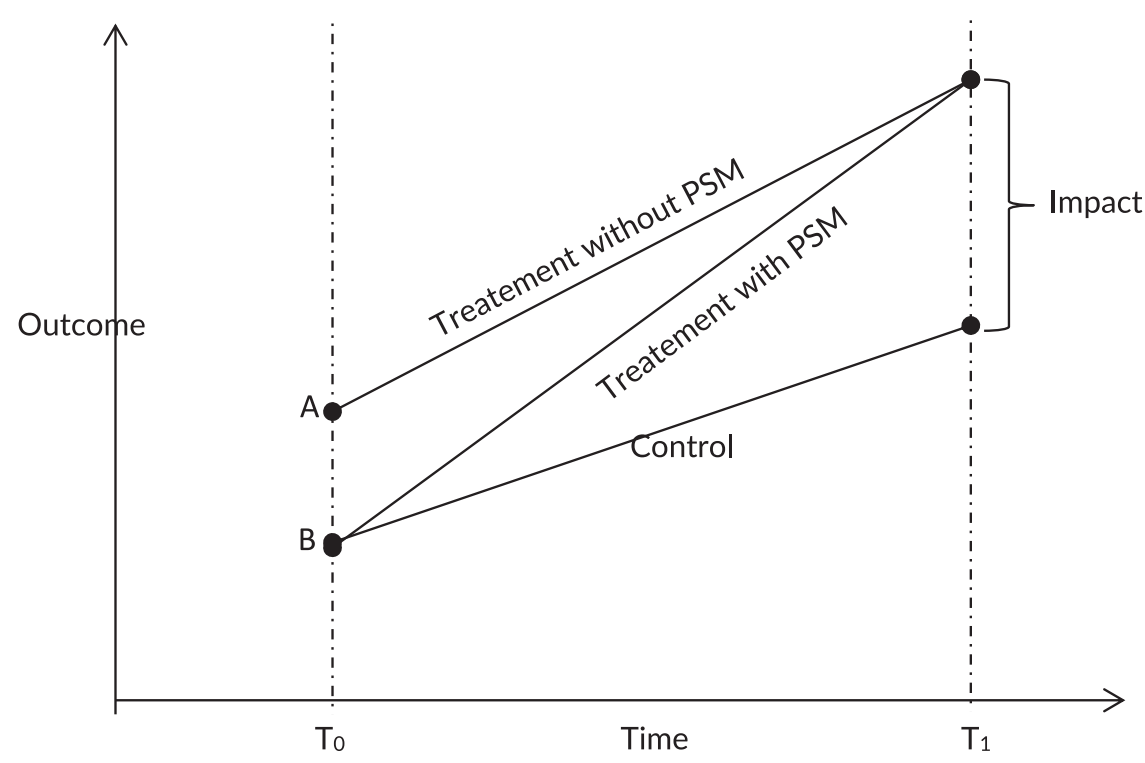

Source: modified by Khandker, et al, (2010)

Community participation (CP) method consists of some models: Kernel Match approach, Nearest Neighbor approach, Radius Match approach, and Stratification Match approach. However, our focus is the Kernel method. This approach is better than the Neighbor approach that uses the procedure bootstapping match of the standard errors (Abadie and Imbens, 2008). After obtain propensity score, and then we carried out the calculation of the average treatment effect on treated (ATT). ATT is used to measure the average differences from the outcome of the group which is located in the family of smokers and lived in the family of smokers with groups that are not in a family of smokers and lived in the family of smokers. But due to the presence of the potential biases that arise from the nature of the data is not random, then the ATT will be combined with the community participation to eliminate the bias: 


$$
A \hat{T} T_{\text {matching }}=\frac{1}{N_{1}} \sum_{i=1}^{N_{1}}\left(y_{1 i}-\sum_{j=1}^{N_{0}} w_{i j} y_{0 j}\right)
$$

where:

$N_{1}=$ The number of children living in the family of smokers

$N_{o}=$ The number of children who do not live in the family of smokers

$y_{1 i}=$ outcome of children who live in the family of smokers

$y_{0 i}=$ outcome of children who do not live in the family of smokers

$w_{i j}=$ the weight where, $\sum_{j=1}^{N_{0}} w_{i j}=1 ; w_{i j} \in[0,1]$

\section{Result and Discussion}

Based on data from Riskesdas 2007 and 2013 shows that the percentage of the population who smoke has increased by $0.6 \%$ (The Ministry of Health of Indonesia, 2015). The tendency of the increase is also supported by IFLS data. Based on IFLS data, smokers increase from $35.3 \%$ (10,248 sample) in 2007 to $36.74 \%(12,591$ sample) in 2014 (See Table 1). Household data for smokers indicate the same trends where in 2007 there were 8,191 households with active smokers and the active smokers increased into 10,129 households in the year 2014 (See Figure 3). Comparing the percentage of household smokers and non-smokers household as well as individual smokers, it can be said that household with smokers has at least 2 active smokers. Figure 3 shows that during 2007 and 2014, an average of 50\% household with smokers occupied by two people smokers and approximately $20 \%$ household occupied by three people smokers. This implicated against the number of household spending on cigarettes. The results of the research done by the Demographic Institute of the Universitas Indonesia (2010), shows that during the period of 2003, 2005, and 2008, the percentage of household monthly spending for cigarettes/ tobacco was higher than the expenditure for the spending for education, health cost, meat, milk and eggs, and fish.

Table 1. The Number and Percentage of Individual Smokers in Indonesia

\begin{tabular}{lrrrrrrrr}
\hline & \multicolumn{9}{c}{2007} \\
\cline { 2 - 9 } Household & \multicolumn{2}{c}{ Individual } & \multicolumn{1}{c}{ Household } & \multicolumn{2}{c}{ Individual } & \multicolumn{2}{c}{ Household } \\
\cline { 2 - 10 } & Number & $\%$ & Number & $\%$ & Number & $\%$ & Number & $\%$ \\
\hline Smokers & 10,248 & 35.30 & 8,191 & 64.58 & 12,591 & 36.74 & 10,129 & 68.10 \\
Not Smokers & 18,784 & 64.70 & 4,493 & 35.42 & 21,680 & 63.26 & 4,744 & 31.90 \\
The Total & 29,032 & 100.00 & 12,684 & 100.00 & 34,271 & 100.00 & 14,873 & 100.00 \\
\hline
\end{tabular}

Source: IFLS4 and IFLS5

The smoking habit of Indonesian is dominated by the cigarette/cigars and tends to increase by 0.03 percent during 2007 and 2014. Comparing with data of Riskesdas 2007, 2010, and 2013 it is indicated the trend of the age started smoking, where the average age 
start smoking is the amount of time 15-19 years, and there is a tendency in the group after 10-14 years also increased steadily (The Ministry of Health of Indonesia, 2015). Easy access to buying cigarettes/cigars and almost no regulation for prohibiting people smoking in public areas are two factors that induce people to start smoke cigarette. Low cigarette price and the consumer can buy the cigarette in the small package also induce low-income consumer can enjoy the smoke cigarette at any time.

Figure 3. The Frequency of The Individual Based on The Number of Smokers in The Household

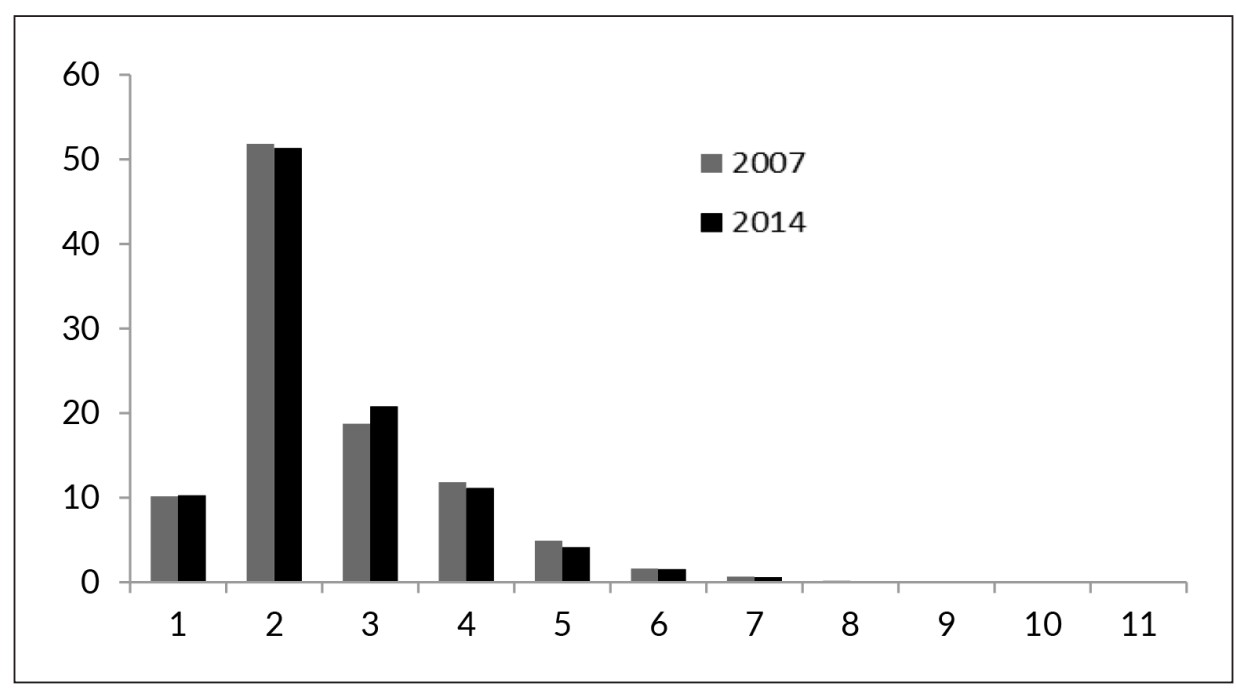

Research related to the impact of prioritizing smoking against outcome on children is still limited; instead, it focuses on smokers themselves. Most empirical studies applied self-reported indicator, but there is a growing number of studies apply Randomize Control Treatments (RCTs). RCTs approach is used to control the effects of smoking before treatment is done. The RCTS separates the difference between the treatment and control groups can be verified by prioritizing smoking characteristics from someone or household. This research does not use the RCTS approach but non-experimental approach to control the bias of estimates produced. The Bias occurs because of the difference between the characteristics of the group treatment and control groups before the existence of the program that is called by the selection bias (Khandker et al., 2010). It is required a method to assess the impact of prioritizing smoking against the condition of counterfactual. The counterfactual situation is the condition that illustrates outcome from a group of treatment when treatment groups are not in the family of smokers. One of the techniques to overcome the main problem in evaluating the impact of smoking behavior is by using the Propensity Score Matching (PSM). PSM method finds the group treatment and control that have similarities or common support. So the difference between the treatment and control groups only caused by the existence of prioritizing smoking from parents or other people in the family who smoke. 


\section{Figure 4. The Results of Community Participation Before and After The Process of Matching}
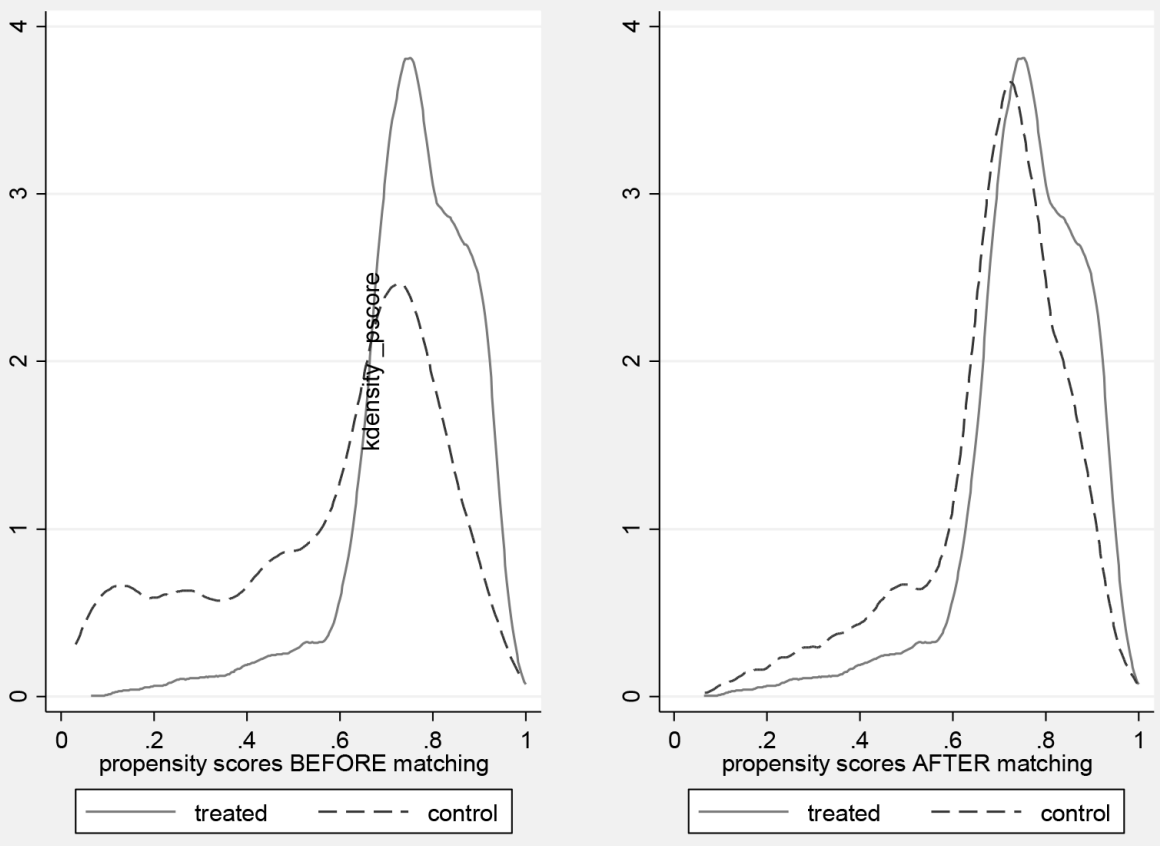

Figure 4 shows that household's characteristic where children lived between the household groups smokers with household, not smokers prior match is quite different. Differences in household characteristic are verified from the individual characteristic of the head of the household, such as age, gender, and long schools. It can also be verified by household characteristics (the number of people living in the house, household spending and the number of household members working age). After the match, so it can be seen that the differences between the characteristics of the group treatment and control are no different.

The impact of the existence of the good parents or others who is in a family to the quality of the health of children in the future will come (underweight, normal, overweight, or obesity) is positive on all types of measuring the match that used. This means that the household smokers have the quality of children in the future is lower compared with the children in the family is not a smoker. Children who are in the family of smokers have probabilities health problems (underweight, overweight, or obesity) 3.6 - 4.8 percent compared with children who lived not with smokers. The results of Holtcamp (2012) and Thayer et al. (2012) reveal that the influence of the environment has a vital role in the condition of obesity of children. There is evidence that children exposed to smoke tend to be obese as they tend to smoke and take snack and drink at the same time. They do this package of consumption more frequently as part of leisure. Therefore, Holtcamp (2012) conclude that smokers tend to experience obese. Other research indicates that children age below ten years experiencing obesity positively associated with children who are exposed to cigarettes (Wen et al., 2013; Yang et al., 2013). 
Table 2. The Value of ATT to Outcome Status of Body Mass Index (BMI) and Cognitively Intact Function

\begin{tabular}{lcc}
\hline \multicolumn{1}{c}{ Variable } & The status of the body mass index (BMI) & Cognitively intact Function \\
\hline \multirow{2}{*}{ t-test } & $0.0363^{* * *}$ & $-1.222^{* * *}$ \\
& $(0.0109)$ & $(0.359)$ \\
Nearest Neighbor & $0.0474^{* *}$ & $-1.416^{*}$ \\
& $(0.0232)$ & $(0.859)$ \\
Radius Match & $0.0393^{* * *}$ & $-1.991^{* * *}$ \\
& $(0.0147)$ & $(0.199)$ \\
Karnel Match & $0.0403^{* * *}$ & $-1.549^{* * *}$ \\
& $(0.0132)$ & $(0.246)$ \\
Stratification Match & $0.0483^{* * *}$ & $-1.451^{* * *}$ \\
& $(0.0105)$ & $(0.363)$ \\
\hline Observations & 9,452 & 9,452 \\
\hline
\end{tabular}

Description: Standard error in brackets, ${ }^{* * *} \mathrm{p}<0.01,{ }^{* *} \mathrm{p}<0.05,{ }^{*} \mathrm{p}<0.1$

The outcome on cognitively intact function shows that children who live in the family of smokers have cognitively intact function is lower compared with children who live in the non-smokers family. The difference from both groups, ranged from 1.22 point to 1.99 points. Chen et al. (2013) shows that children who are exposed to cigarettes (secondhand smoke), tend to have the academic achievements and lower neurocognitive performance.

Indonesia is the third countries with the most significant population in the world. Indonesia is one of the destinations for the world's tobacco markets. As one of the world market for tobacco, the government of Indonesia introducing regulation number 109 in 2012. This rule regulates and controllers the promotion and advertisement of cigarettes and its distribution. However, regarding implementation until now low enforcement is implemented in Indonesia. People still smoke in public transport, except train and aircraft. Children below 18 years old can buy cigarette easily and low price, as they can buy in retail. Excessive cigarette advertisements with positive and gentle images easily influence children as early smokers. On the other side, parent and adult's smoking habit also influence child decided to become an earlier smoker. Constant exposure to smoke, not only affect children decide to become smoker but also change their health status in the long run. Low health status as effects of exposure from cigarette smoke indirectly will lower the quality of human capital in the future.

Smokers in Indonesia do not care for environment and health impact on passive smokers. Majority adult smokers smoke in public areas as well as in-house. Lack of awareness of environment and health impact from adult smokers potentially transmitted to the children who also become early smokers. Our findings show that $70,75 \%$ of children are exposed as a secondhand smoker at home. Furthermore, the proportion of this exposure is higher in rural than in urban areas. Although there is awareness of the health effects of smoking among parents, smokers behavior do not change practice. There is a common belief that improving adult smokers and household wife knowledge and awareness, negative effects of cigarette smoke can be eliminated slowly. 
Table 2 shows that children who live in the family of smokers have lower health status and educational attainment in the future. Riskesdas 2007, 2010, and 2013 shows that the majority of people who smoke is located in a low-income quantile (The Ministry of Health of Indonesia, 2015). This result shows the bottom of the children who do not prosper is the children who live in low-income families. The unfavour condition for children caused by various factors including First, the knowledge of the parents of smoking effects to their children; and Second, the existence of the rules governing the limitation of age for accessing cigarettes.

Smokers have a risk of bad health status is greater compared with those who do not smoke. The negative effect appears in the long run as the effects of cigarette lowering individual body immune. In the long run, there is a lag between consumption and risk due to smoking. The lag causes the individual not aware the negative consequences of making a decision either to smoke or not. The individual does not care about the health risks of smoking. The general public poorly understands health risks. The lack of awareness and over-optimism of individuals on the effects of smoking, as well as the time lag between consumption and the impact of smoking on health, causes individuals not to consider the health consequences of smoking, although smoking can have adverse health consequences for non-smokers through second-hand smoke.

Besides affecting the health of children, smoking at home also has an impact on the level of education of their children. Our results show that smoking can decrease the level of child education measured by cognitively intact function. This result is in line with some previous research showing that secondhand smokers have associations with low cognitive function with various outcomes (Cho et al., 2010; Jedrychowski et al., 2009; Lee et al., 2011). Toxic chemicals derived from cigarettes are very harmful to the brain nerves which then decrease the level of intelligence of the child, for example, increased levels of monoxide into the blood can affect the flow of oxygen to the brain (Mezzacappa et al., 2011). Also, the nicotine and mercury levels present in cigarette smoke will affect the cholinergic system that possible lead to overstimulation of neurons and for a long time will have an impact on nerve paralysis and ultimately impact on learning and memory (Chen et al., 2013).

Other study found that smokers tend to have higher time preference. In other words, smokers tend to be impatient. The level of time preference to the age of those smoking turns higher compared with those who do not smoke, 13.8\% and 8.1\% (Scharff and Viscusi, 2011). This means that smokers prefer to lose the time of life in the future to consume cigarettes today. High time preference is caused by several factors: the level of education and the direct effect of consuming cigarettes today. The research result Riskesdas 2007, 2010, and 2011 shows that those who smoke tend to have a low level of education (The Ministry of Health of Indonesia, 2015). Also, the smoker does not directly feel the impact of cigarettes. This condition induces smokers tend to remain to smoke.

Free access to cigarettes also lead all people to all types of the age and income can buy cigarettes easily. In the United States based on data Monitoring the Future Survey, showed that $47.0 \%$ children on the level of eight and two-thirds of the level of ten stated that they are smoking because it is easy to buy. In Indonesia, regulations made by the government do 
not protect consumers from the dangers of smoking. This is a difference with the regulations related to alcohol; where there are rules that restrict children under the age of 18 cannot buy drink contain alcohol.

The negative impact of cigarettes on children might not determine as an important issue in Indonesia. This research provides empirical evidence how cigarette smoke exposure on children has an impact on their health status and educational attainment in their later life. This fact may be especially in more impoverished and rural areas. Low quality of human capital as aggregate will deteriorate development process in Indonesia.

\section{Conclusion}

The findings indicate that secondhand smoker (children who are in the family of smokers) have the lower level of health and education which compared with children who are in the family, not smokers. The average probability for children experiencing health problems such as underweight, overweight, and obesity based on various measurements are 4.23 percent. Measurement for cognitively intact function analysis results showed that the average children secondhand smoker have an average of cognitively intact function lower about 1.53 point compared with children who are not in the family with smokers.

The condition of the above shows that the cigarettes not only have an impact on the active smoker but also on smokers passively. So the government needs to create a regulation that restricts access to cigarettes/cigars. Also, the level of understanding of parents especially those who are in the lowest income groups need to be improved through various socializations either directly or indirectly.

It might be better to increase the knowledge and awareness of housewife related to the long-term effects of smoking on children. Household wife acts actively reminding their family of avoiding smoke at the house due to adverse effects on air circulation. These environmental tobacco smoke (smoke at home) are having a negative impact on families members' health. Therefore, government or local government should increase awareness by regulating banned to smoke in public areas, such as rest areas and public transportation.

\section{References}

Abadie, A., \& Imbens, G. W. (2008). On the Failure of the Bootstrap for Matching Estimators. Econometrica. Vol. 76 (6): 1537-1557.

Becker, G. S., \& Tomes, N. (1986). Human Capital and The Rise and Fall of Families. Journal of Labor Economics. Vol. 4 (3): S1-S39.

Best, C. M., Sun, K., De Pee, S., Bloem, M. W., Stallkamp, G., \& Semba, R. D. (2007). Parental Tobacco Use is Associated With Increased Risk of Child Malnutrition in Bangladesh. Nutrition. Vol. 23 (10): 731-738.

Case, A., \& Deaton, A. S. (2005). Broken Down by Work and Sex: How Our Health Declines. In Wise \& David (Eds.), Analyses in the Economics of Aging. Chicago: University of Chicago Press. pp. 185-212. 
Chen, R., Clifford, A., Lang, L., Anstey. K. J. (2013). Is Exposure to Secondhand Smoke Associated With Cognitive Parameters of Children and Adolescents? a Systematic Literature Review. Annals of Epidemiology. Vol. 23 (10): 652-661.

Cho, S. C., Kim, B. N., Hong, Y. C., Shin, M. S., Yoo, H. J., Kim, J. W., Bhang, S. Y., Cho, I. H., \& Kim, H.W. (2010). Effect of Environmental Exposure To Lead and Tobacco Smoke on Inattentive and Hyperactive Symptoms and Neurocognitive Performance in Children. Journal of Child Psychology and Psychiatry. Vol. 51 (9): 1050-1057.

Cook, D. G., \& Strachan, D. P. (1997). Health Effects of Passive Smoking. 3. Parental Smoking and Prevalence of Respiratory Symptoms and Asthma in School Age Children. Thorax. Vol. 52 (12): 1081-1094.

Cook, D. G., Strachan, D. P., \& Carey, I. M. (1998). Parental Smoking and Spirometric Indices in Children. Thorax. Vol. 53 (10): 884-893.

Duelien, T., Eagan, T., Eide, G., Gulsvik, A., \& Bakke, P. (2005). The Adult Incidence of Asthma and Respiratory Symptoms by Passive Smoking in Utero or in Childhood. European Respiratory Review. Vol. 172 (1): 61-66.

Efroymson, D., Ahmed, S., Townsend, J., Alam, S. M., Dey, A. R., Saha, R., Dhar, B., Sujon, A. I., Ahmed, K. U., \& Rahman, O. (2001). Hungry For Tobacco: an Analysis of The Economic Impact of Tobacco Consumption on The Poor in Bangladesh. Tobacco Control. Vol. 10 (3): 212-217.

Eriksen, M., Mackay, J., Schluger, N., Islami, F., \& Drope, J. (2015). The Tobacco Atlas. Atlanta, Georgia: American Cancer Society.

Heckman, J. J., \& Masterov, D. V. (2007). The Productivity Argument for Investing in Young Children. Applied Economic Perspectives and Policy. Vol. 29 (3): 446-493.

Heckman, J. J., \& Robb, R. (1985). Alternative Methods for Evaluating The Impact of Interventions: An Overview. Journal of Econometrics. Vol. 30 (1-2): 239-267.

Hill, K. G., Hawkins, J. D., Catalano, R. F., Abbott, R. D., \& Guo, J. (2005). Family Influences on The Risk of Daily Smoking Initiation. Journal of Adolescent Health. Vol. 37 (3): 202-210.

Holtcamp, W. (2012). Obesogens: An Environmental Link to Obesity. Environmental Health Perspectives. Vol. 120 (2): A63-A68.

Jedrychowski, W., Perera, F., Jankowski, J., Mrozek-Budzyn, D., Mroz, E., Flak, E., Edwards, S., Skarupa, A., \& Lisowska-Miszczyk, I. (2009). Gender Specific Differences in Neurodevelopmental Effects of Prenatal Exposure to Very Low-Lead Levels: The Prospective Cohort Study in Three-Year Olds. Early Human Development. Vol. 85 (8): 503-510.

Johnson, R. C., \& Schoeni, R. F. (2011). The Influence of Early-life Events on Human Capital, Health Status, and Labor Market Outcomes Over The Life Course. The BE Journal of Economic Analysis \& Policy. Vol. 11 (3): 1-48.

Khandker, S. R., Koolwal, G. B., \& Samad, H. A. (2010). Handbook on Impact Evaluation: Quantitative Methods and Practices. Washington DC: IBRD/World Bank. 
Lee, B. E., Hong, Y. C., Park, H., Ha, M., Kim, J. H., Chang, N., Roh, Y. M., Kim, B. N., Kim, Y., \& Oh, S. Y. (2011). Secondhand Smoke Exposure During Pregnancy and Infantile Neurodevelopment. Environmental Research. Vol. 111 (4): 539-544.

Lembaga Demografi Universitas Indonesia. (2010). Dampak Tembakau dan Pengendaliannya di Indonesia (The Impact of Tobacco and The Control in Indonesia). Jakarta: Lembaga Demografi Universitas Indononesia.

Leonardi-Bee, J., Jere, M. L., \& Britton, J. (2011). Exposure to Parental and Sibling Smoking and The Risk of Smoking Uptake in Childhood and Adolescence: a Systematic Review and Meta-analysis. Thorax. Vol. 66 (10): 847-855.

Mezzacappa, E., Buckner, J. C., \& Earls, F. (2011). Prenatal Cigarette Exposure and Infant Learning Stimulation as Predictors of Cognitive Control in Childhood. Developmental Science. Vol. 14 (4): 881-891.

Moshammer, H., Hoek, G., Luttmann-Gibson, H., Neuberger, M. A., Antova, T., Gehring, U., Hruba, F., Pattenden, S., Rudnai, P., \& Slachtova, H. (2006). Parental Smoking and Lung Function in Children: an International Study. American Journal of Respiratory and Critical Care Medicine. Vol. 173 (11): 1255-1263.

Nageris, B., Braverman, I., Hadar, T., \& Hansen, M. C. (2001). Effects of Passive Smoking on Odour Identification in Children. Journal of Otolaryngology-Head \& Neck Surgery. Vol. 30 (5): 263-265.

Priest, N., Roseby, R., Waters, E., Polnay, A., Campbell, R., Spencer, N., Webster, P., \& Ferguson-Thorne, G. (2008). Family and Carer Smoking Control Programmes for Reducing Children's Exposure to Environmental Tobacco Smoke. Cochrane Database of Systematic Reviews, Issue 4. doi: https://doi.org/10.1002/14651858.CD001746. pub2.

Pust, S., Mohnen, S., \& Schneider, S. (2008). Individual and Social Environment Influences on Smoking in Children and Adolescents. Public Health. Vol. 122 (12): 1324-1330.

Scharff, R. L., \& Viscusi. (2011). Heterogeneous Rates of Time Preference and The Decision to Smoke. Economic Inquiry. Vol. 49 (4): 959-972.

Semba, R. D., De Pee, S., Sun, K., Best, C. M., Sari, M., \& Bloem, M. W. (2008). Paternal Smoking and Increased Risk of Infant and Under-5 Child Mortality in Indonesia. American Journal of Public Health. Vol. 98 (10): 1824-1826.

Semba, R. D., Kalm, L. M., de Pee, S., Ricks, M. O., Sari, M., \& Bloem, M. W. (2007). Paternal Smoking is Associated With Increased Risk of Child Malnutrition Among Poor Urban Families in Indonesia. Public Health Nutrition. Vol. 10 (1): 7-15.

Strachan, D. P., \& Cook, D. G. (1997). Health Effects of Passive Smoking: Parental Smoking and Lower Respiratory Illness in Infancy and Early Childhood. Thorax. Vol. 52 (10): 905-914.

Thayer, K. A., Heindel, J. J., Bucher, J. R., \& Gallo, M. A. (2012). Role of Environmental Chemicals in Diabetes and Obesity: a National Toxicology Program Workshop Review. Environmental Health Perspectives. Vol. 120 (6): 779-789. 
The Ministry of Health of Indonesia. (2015). Prilaku Merokok Masyarakat Indonesia The Smoking Behavior of Indonesian People). Jakarta: Kementerian Kesehatan Republik Indonesia.

Wen, X., Shenassa, E. D., \& Paradis, A. D. (2013). Maternal Smoking, Breastfeeding, and Risk of Childhood Overweight: Findings from a National Cohort. Maternal and Child Health Journal. Vol. 17 (4): 746-755.

Yang, S., Decker, A., \& Kramer, M. S. (2013). Exposure to Parental Smoking and Child Growth and Development: a Cohort Study. BMC Pediatrics. Vol. 13 (104): 1-10. 